\title{
GEOMETRIC REPRESENTATIONS OF EQUILIBRIUM CURVES OF A COMPRESSED STIFFENED PLATE
}

\author{
Gaik A. Manuylov, Sergey B. Kosytsyn, Irina E. Grudtsyna
}

Russian University of Transport (RUT - MIIT), Moscow, RUSSIA

\begin{abstract}
The work is aimed at studying the solutions of the stability problem (subcritical and postcritical equilibrium) of an infinitely wide regular compressed reinforced plate, using a selected T-shaped fragment that is equally stable with others. The authors have given a classification of possible analytical solutions for these plates. The results of the work are presented in the form of variants of spatial bifurcation diagrams, values of critical loads, as well as coordinates of singular points for different cases of solutions.
\end{abstract}

Keywords: stability, stiffened plate, post-critical equilibrium, critical load, bifurcation curve

\section{ГЕОМЕТРИЧЕСКИЕ ПРЕДСТАВЛЕНИЯ КРИВЫХ РАВНОВЕСИЯ СЖАТОЙ ПОДКРЕПЛЕННОЙ ПЛАСТИНЫ}

\author{
Г.А. Мануйлов, С.Б. Косицын, И.Е. Грудџына \\ Российский университет транспорта (МИИТ), г. Москва, РОССИЯ
}

\begin{abstract}
Аннотация: работа направлена на исследование решений задачи устойчивости (докритического и послекритического равновесия) бесконечно широкой регулярной сжатой подкрепленной пластины, при помощи выделенного, равноустойчивого с другими Т-образного фрагмента. Авторами дана классификация возможных аналитических решений для данных пластин. Результаты работы представлены в виде вариантов пространственных бифуркационных диаграмм, значений критических нагрузок, а также координат сингулярных точек для различных случаев решений.
\end{abstract}

Ключевые слова: устойчивость, подкрепленная пластина, послекритическое равновесие, критическая нагрузка, бифуркационная кривая

\section{INTRODUCTION}

Algorithms for solving the problem of stability of reinforced plates have been described by a fairly large number of authors, starting from the $50 \mathrm{~s}$ of the twentieth century $[1,3,5,7,10,11]$. However, the main and extremely important research factor that unites all works on this topic is the interaction of its own forms (general and local forms of loss of stability). It is the interaction of forms that affects the bearing capacity of the reinforced plate, significantly reducing it in a number of cases. In this article, for the first time, a qualitative study of post-critical equilibria is presented, and a laconic classification of possible solutions presented in the form of spatial bifurcation diagrams is given.

\section{PROBLEM FORMULATION}

An infinitely wide reinforced plate is considered. Physical characteristics of the material:

$$
E=2 \cdot 10^{6} \mathrm{~kg} / \mathrm{cm}^{2}, \mu=0.3 \text {. }
$$

Boundary conditions: the plate is hingedsupported at the ends, the longitudinal edges are free. Figure 1 shows a cross-section of a reinforced plate with corresponding dimensions. 


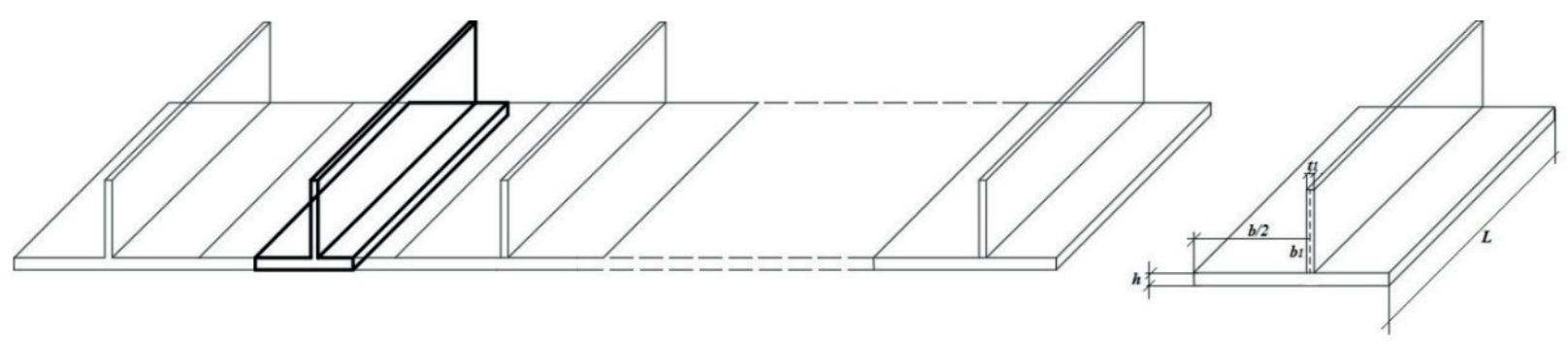

Figure 1. The plate cross section

Here $b-$ is the distance between the ribs in the axes, $h$ - is the thickness of the plate, $b_{1}$ - is the height of the rib, $t_{1}-$ is the thickness of the rib, $L-$ is the length of the reinforced plate.

Let us analyze the equilibrium of one T-shaped fragment of the reinforced plate, which is equally stable with the others. Boundary conditions for it: hinged support along the short sides, along the longitudinal edges, fastening of the movable termination type (Figure 2). A compressive force is applied at the center of gravity of the section.
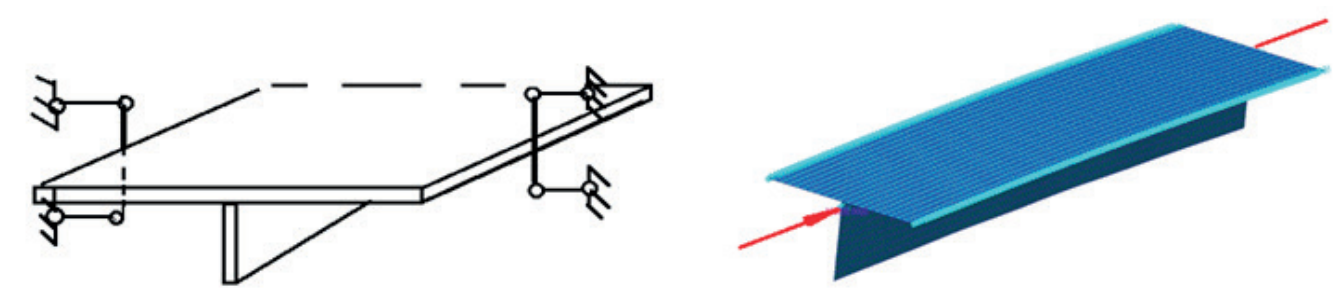

Figure 2. Conditions for fixing and finite-element model of the T-shaped fragment

\section{CLASSIFICATION OF POSSIBLE SOLUTIONS}

A reinforced plate is an example of an asymmetrical structure that consists of elements: a plate (sheathing) and reinforcing ribs. This design has several forms of buckling:

$>$ the general shape, which is a half-wave of a sinusoid, which is close to the bulge shape of a wide Euler strut; local forms of wave formation.

Under central compression, a general deflection develops towards a more rigid element, i.e. if the reinforcing ribs are weaker in relation to the plate, then the deflection develops on the side of the plate, so that the ribs turn out to be on the concave side (Figure 3a). If the plate is conditionally "weak", then the edges turn out to be on the convex side (Figure $3 \mathrm{~b}$ ). Thus, the general form of buckling is characterized by the deflection direction.

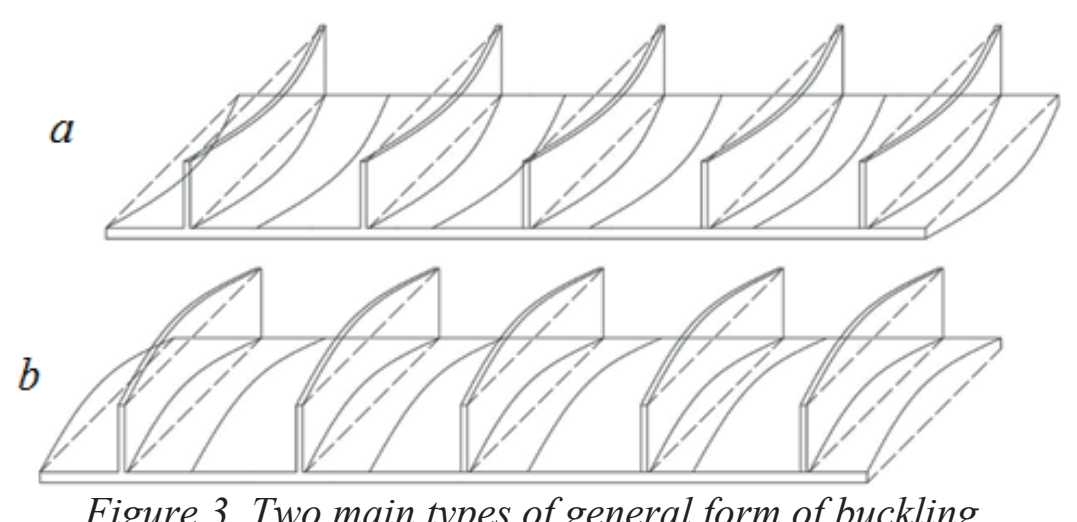

Figure 3. Two main types of general form of buckling 
Considering the internal forces arising from the compression of the reinforced plate, it can be concluded that along with the compressive force, due to the inevitable small eccentricities, an internal bending moment also appears, and the more the deflection increases, the more the influence of this moment is manifested. In the usual understanding of the linear stability problem, any structure has linearly independent (orthogonal), and therefore independent from each other forms, they can be observed when solving buckling in any finite element complex. However, the nonlinear solution shows that the general shape with increasing deflection sooner or later generates a new one - wave formation in the plate or reinforcing ribs (Figure 4). Wave formation of the plate is possible when the ribs are in the stretched bending zone, and the plate is in the compressed one. Wave formation in the reinforcing ribs develops in the opposite direction of the general deflection.
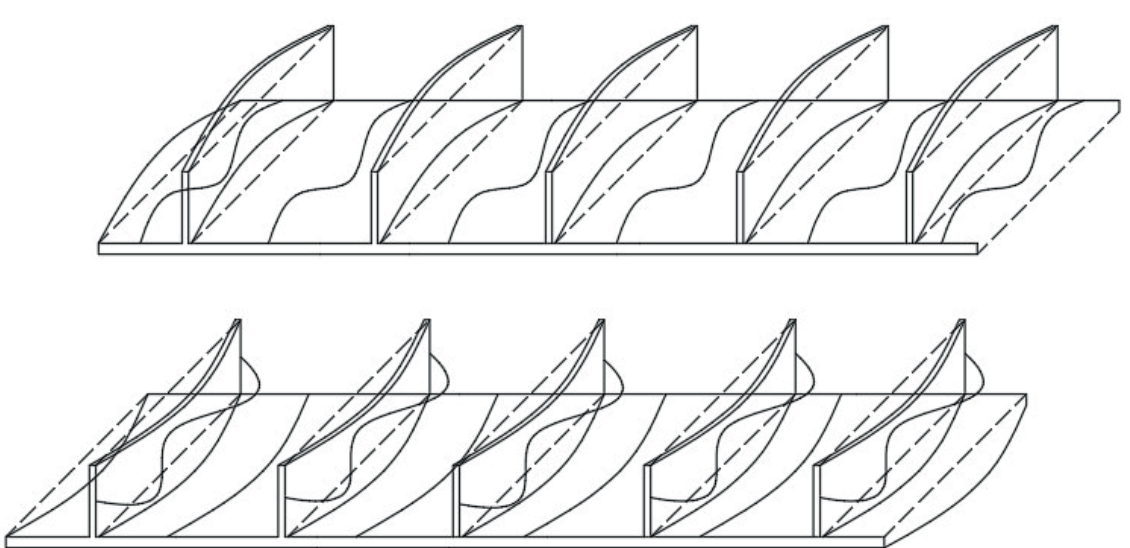

Figure 3. Local forms of buckling in the plate or in the stiffeners

The expression for the total potential energy of interaction of two forms of loss of stability $(\mathrm{s}=$ a compressed reinforced plate in the case of 2) has the form:

$$
\begin{gathered}
\Pi_{\ni}=a_{0}+\frac{1}{2} a_{1}\left(1-\frac{\lambda}{\lambda_{1}}\right) \xi_{1}^{2}+\frac{1}{2} a_{2}\left(1-\frac{\lambda}{\lambda_{2}}\right) \xi_{2}^{2}+\frac{1}{3} a_{111} \xi_{1}^{3}+a_{122} \xi_{1} \xi_{2}^{2}+\frac{1}{4} a_{1111} \xi_{1}^{4}+ \\
+\frac{1}{4} a_{2222} \xi_{2}^{4}+\frac{1}{2} a_{1122} \xi_{1}^{2} \xi_{2}^{2}-\frac{\lambda}{\lambda_{1}} a_{1} \overline{\xi_{1}} \xi_{1}-\frac{\lambda}{\lambda_{2}} a_{2} \overline{\xi_{2}} \xi_{2}
\end{gathered}
$$

where: $\xi-$ are normalized eigenforms (the amplitude of the deviation of the eigenmode relative to the plate thickness;

$\lambda$ - is the load parameter;

$\overline{\xi_{s}}-$ are imperfections in the s-th form of buckling $(\mathrm{s}=1,2, \ldots . . \mathrm{n})$.
Coefficients: $a_{111}-$ characterizes the general form of buckling, $a_{122}$-interaction of forms. The first variation of the total potential energy for each form gives the equilibrium equations:

$$
\begin{gathered}
\left(1-\frac{\lambda}{\lambda_{1}}\right) \xi_{1}+d_{1} \xi_{1}^{2}+d_{2} \xi_{2}^{2}=\frac{\lambda}{\lambda_{1}} \overline{\xi_{1}} \\
\left(1-\frac{\lambda}{\lambda_{2}}\right) \xi_{2}+d_{3} \xi_{1} \xi_{2}=\frac{\lambda}{\lambda_{2}} \overline{\xi_{2}}
\end{gathered}
$$


where: $d_{1}=\frac{a_{111}}{a_{1}}, \quad d_{2}=\frac{a_{122}}{a_{1}}, \quad d_{3}=\frac{2 a_{122}}{a_{2}} . \quad \mu_{1}=\frac{\lambda}{\lambda_{1}} \quad \mu_{2}=k \mu_{1}$

$\lambda_{1}$ - is the critical load of the linear calculation of the general form of buckling by the type of an Euler strut;

$\xi_{1}$ - relative amplitude corresponding to the general shape;

$\xi_{2}$ - relative amplitude corresponding to the local form of loss of stability of wave formation (plate or ribs);

$\lambda_{2}$ - waveform load.

The general form of buckling depends only on the direction of the deflection and the corresponding coordinate $\xi_{1}$; all solutions for a given form will be called unbound solutions. In this case, any wave formation (in the plate or reinforcing ribs) is absent $\left(\xi_{2}=0\right)$.

The study of uncoupled solutions is based on considering the equilibrium equations (2) and (3). In the case of an ideal problem (without initial geometric imperfections), the right-hand sides of the equations are zeroed, and under the condition $\left(\xi_{2}=0\right)$ from (2) we obtain the equation of the straight line of the general deflection:

$$
\mu_{1}=d_{1} \xi_{1}+1
$$

and the expression for the coordinate of this straight line:

$$
\xi_{1}=-\frac{\left(1-\mu_{1}\right)}{d_{1}}
$$

The straight line of unbound equilibria is located in the plane $\lambda \xi_{1}$, the geometric meaning of the coefficient $d_{1}$ is expressed in the slope of this straight line. If the coordinate $\xi_{1}>0, d_{1}<$ 0 (always), then $\mu_{1}$ decreases and vice versa (Figure 5). From equation (5) it follows that at a load $\mu_{1}=1$, (i.e., the compression load is equal to the critical load of the linear calculation), a bifurcation point appears, corresponding to the general form of buckling. The birth of bifurcation points is possible only if the system in subcritical equilibrium has an energyorthogonal complement, i.e. there is a possibility of the emergence of new force factors, whose influence on the system forms a new form of equilibrium. In this case, the initial subcritical equilibrium is determined by the action of the compressive load. However, in any case, the development of the general deflection of the reinforced plate arises, and at the same time a new force factor appears - the bending moment. If the problem is considered taking into account the initial deflection $\left(\overline{\xi_{1}} \neq 0\right)$, then the equation for $\mu_{1}$ will take a slightly different form (the equation of imperfect curveshyperbolas tending to a straight line of general deflection):

$$
\mu_{1}=\frac{\xi_{1}\left(d_{1} \xi_{1}+1\right)}{\xi_{1}+\overline{\xi_{1}}}
$$

The local form of wave formation arises with the development of a bending moment and compressive stresses in the middle part of the reinforced plate, the action of which provokes a nonlinear system to self-organization (the definition is given by G.A. Manuylov [7]), this means to a change in the form of buckling, therefore the coordinate $\xi_{2}$ is a function total deflection, i.e. defines the associated strain.

The coupled solutions are divided into two types:

$>$ bifurcation solutions with $\left(\overline{\xi_{1}} \neq 0\right)$ or without the initial deflection $\left(\overline{\xi_{1}}=0\right)$;

solutions with limit point $\left(\overline{\xi_{1}} \neq 0\right.$ и $\left.\overline{\xi_{2}} \neq 0\right)$. From equations (2) and (3) with $\xi_{2} \neq 0$ and disregarding the initial imperfections $\left(\overline{\xi_{1}}=0\right.$ и $\left.\overline{\xi_{2}}=0\right)$ we obtain that:

$$
\xi_{2}=\mp \xi_{1} \sqrt{\frac{d_{3}\left(1-\frac{\lambda}{\lambda_{1}}\right)}{d_{2}\left(1-\frac{\lambda}{\lambda_{2}}\right)}-\frac{d_{1}}{d_{2}}}
$$



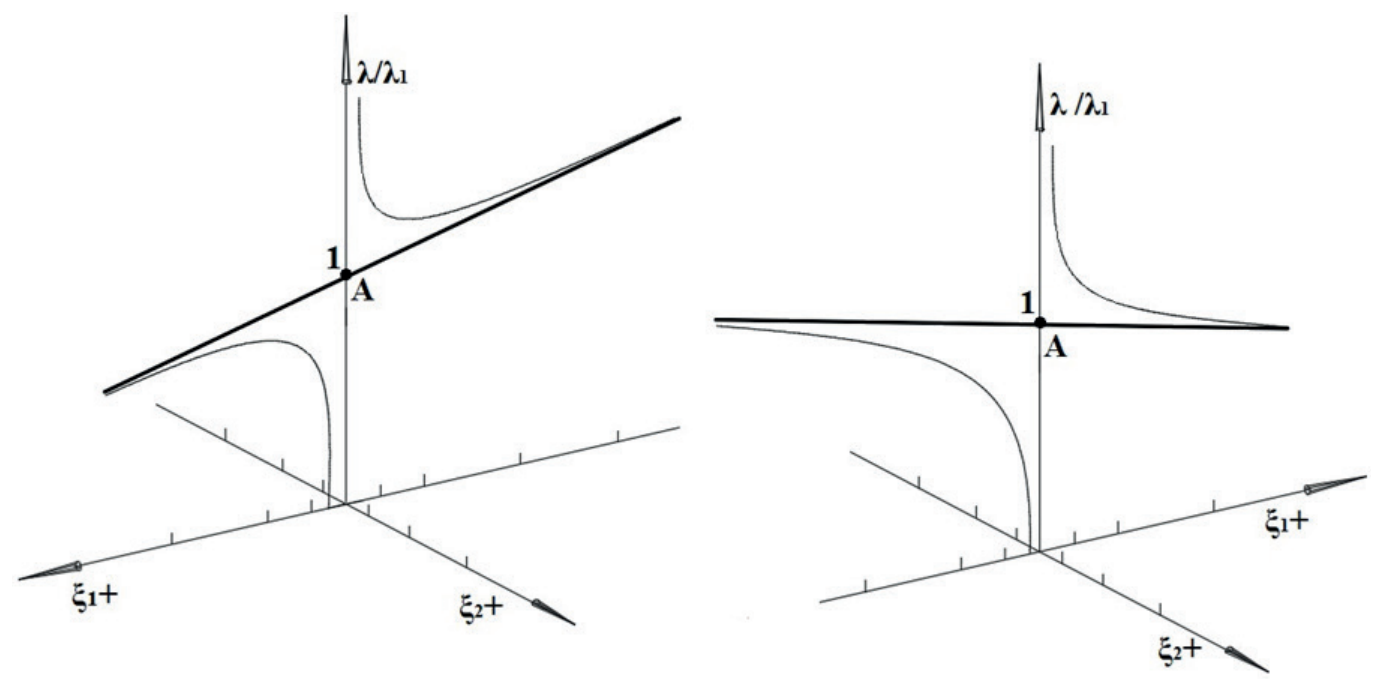

Figure 5. Bifurcation diagrams of unrelated solutions

Equation (7) defines post-bifurcation solutions of coupled equilibria. However, in order to obtain the bifurcation point itself, the condition of equality of the Hessian potential energy to zero is necessary. The Hesse matrix obtained from equations (2) and (3) has the form:

$$
H_{\Pi}=\left[\begin{array}{cc}
\left(1-\frac{\lambda}{\lambda_{1}}\right)+2 d_{1} \xi_{1} & 2 d_{2} \xi_{2} \\
d_{3} \xi_{2} & \left(1-\frac{\lambda}{\lambda_{2}}\right)+d_{3} \xi_{1}
\end{array}\right] .
$$

In the initial subcritical equilibrium, the waveform amplitude $\xi_{2}=0$, since pure compression is in effect. Equality to zero of determinant (8) is reduced to the condition of equality to zero $h_{11}$ or $h_{22}$. Of greatest interest is the inversion of the $h_{22}$ matrix (8), since it is related to the second equilibrium equation.

From the condition, $h_{22}\left(\lambda, d_{3}, \xi_{1}\right)=0$ we obtain an expression for the coordinate of the deflection $\xi_{1}$ at the singular point:

$$
\mu_{1}^{2}\left(k^{2} d_{1}-d_{3} k\right)+\mu_{1}\left(d_{3}+d_{3} k-2 k d_{1}\right)+d_{1}-d_{3}=0
$$

Equation (10) is common to any related solution; the main role in it is played by the coefficients $d_{\mathrm{i}}$. The $d_{1}$ coefficient is always less than zero, the signs of the $d_{2}$ and $d_{3}$ coefficients indicate the nature of the wave formation. If $d_{2}>0$ and $d_{3}>0$, then wave formation should be expected in the reinforcing ribs.
Accordingly, if $d_{2}<0, d_{3}<0$, then wave formation will appear in the plate (skin). The values of the coefficients $d i(i=1,2,3)$ are taken from the work of A.I. Manevich [11] for different cases of related solutions. For the case of wave formation in the reinforcing edges, the values of the coefficients are: 
$d_{1}=-0.009, d_{2}=1.024, d_{3}=0.975$, $k=\frac{\lambda_{1}}{\lambda_{2}}=1.4852$.

Then equation (10) will take the form:

$$
\mu_{1}^{2}-1.6688 \mu_{1}+0.67=0
$$

The roots of the equation are the values of the bifurcation load of wave formation in the edges:

$\mu_{1(1)}=0.6733$ и $\mu_{1(2)}=0.99558$.

For another plate, in which wave formation occurs in the skin, the values of the coefficients $d_{\mathrm{i}}$ are as follows:

$$
\begin{aligned}
& d_{1}=-0.0069, d_{2}=-0.503 \\
& d_{3}=-0.051, k=\frac{\lambda_{1}}{\lambda_{2}}=1.287
\end{aligned}
$$

Equation (10) will take the form:

$$
\mu_{1}^{2}-1.8338 \mu_{1}+0.81351=0
$$

The values of the bifurcation load of wave formation in the plate:

$$
\mu_{1(1)}=1.0459 \text { и } \mu_{1(2)}=0.777 \text {. }
$$

Figure 6 shows a bifurcation diagram of coupled solutions (waving in reinforcing ribs). Figure 7 is a bifurcation diagram of coupled solutions (wave formation in a plate).

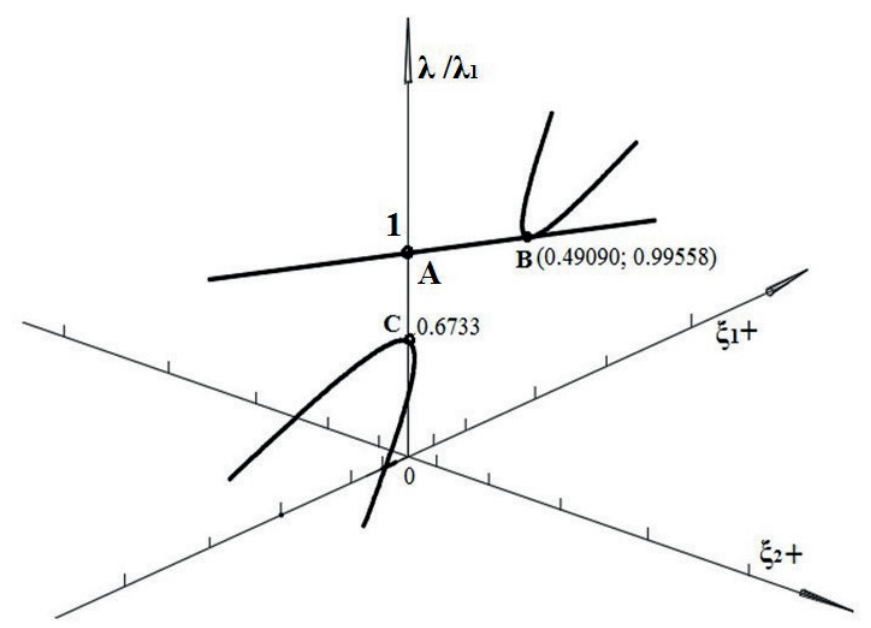

Figure 6. Bifurcation diagrams of related solutions (wave making of the stiffeners)

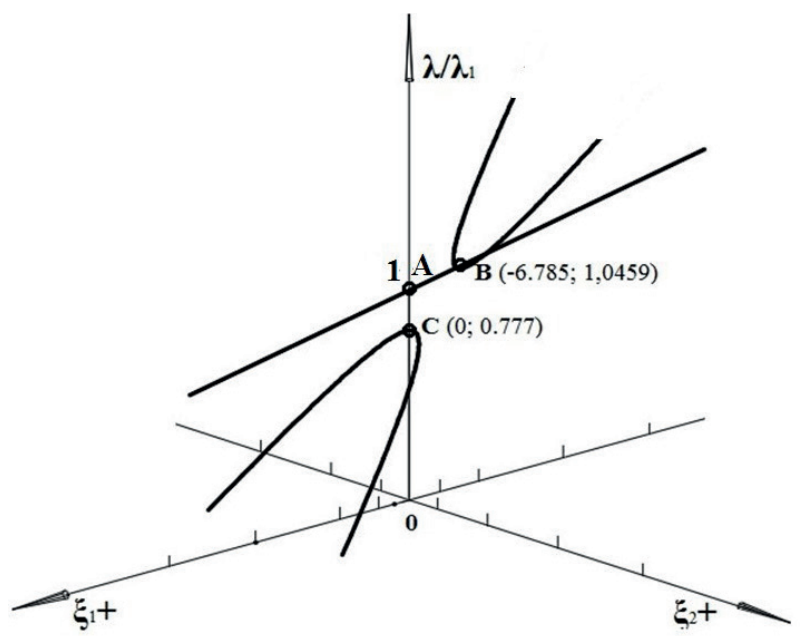

Figure 7. Bifurcation diagrams of related solutions (wave making of the plate) 
In diagrams 6 and 7 , point $\mathrm{A}$ is a bifurcation point in the general shape, $\mathrm{B}$ and $\mathrm{C}$ are wave formation bifurcations. As can be seen from the diagrams, the critical load of wave formation in both cases is lower than the load corresponding to the shape of the total deflection. This indicates a loss of bearing capacity near the critical waveform load. If the ribs are in the compressed zone and lose stability, then the difference between the critical load of nonlinear and linear calculations can reach up to $60 \%$ [7], [11]. If the plate loses its stability, the difference can be in the range of $15 \%-30 \%$. All new postbifurcation coupled solutions are located in planes inclined to the plane $\xi_{2} 0 \lambda$.. All of these solutions are unstable because the Hessian matrix is not positive definite, since $h_{22}\left(\lambda, d_{3}, \xi_{1}\right)=0$ not only at the bifurcation point, but also along all curves $\xi_{2}$. The case of coupled buckling in the presence of initial deflection has a completely different form. Consider two options for the initial deflection:

$>\overline{\xi_{1}}=-0.5$ (wave formation in the edges);

$>\overline{\xi_{1}}=0.5$ (wave formation in the plate);

$\overline{\xi_{1}}-$ is the amplitude related to the thickness of the plate (skin). Then the equilibrium equations (2) and (3):

Then the equilibrium equations (2) and (3):

$$
\begin{gathered}
\left(1-\frac{\lambda}{\lambda_{1}}\right) \xi_{1}+d_{1} \xi_{1}^{2}+d_{2} \xi_{2}^{2}=\frac{\lambda}{\lambda_{1}} \overline{\xi_{1}} \\
\left(1-\frac{\lambda}{\lambda_{2}}\right) \xi_{2}+d_{3} \xi_{1} \xi_{2}=0
\end{gathered}
$$

And equation (10), compiled taking into account the initial imperfections, will be written as follows:

$$
\mu_{1}^{2}\left(k^{2} d_{1}-d_{3} k\right)+\mu_{1}\left(d_{3}+d_{3} k-2 k d_{1}-d_{3}^{2} \overline{\xi_{1}}\right)+d_{1}-d_{3}=0
$$

The $\xi_{1}$ coordinate is calculated in the same way as in the previous cases; however, postbifurcation solutions will depend on the imperfection amplitude $\overline{\xi_{1}}$ :

$$
\xi_{2}=\mp \sqrt{\frac{\bar{\xi}_{1} \mu_{1}-d_{1} \xi_{1}^{2}-\left(1-\mu_{1}\right) \xi_{1}}{d_{2}}}
$$

Equation (17) corresponding to the negative value of the deflection has the form:

$$
\mu_{1}^{2}-1.9926 \mu_{1}+0.67=0
$$

The critical loads of wave formation in the ribs have the following values:

$$
\mu_{1(1)}=1.564 \text { и } \mu_{1(2)}=0.428
$$

The bifurcation diagram is shown in Figure 8.
As can be seen from this graph, the values of bifurcation loads are lower than in the case of solutions without initial imperfections. The bifurcation points of wave formation $\mathrm{B}$ and $\mathrm{C}$ appear on unconnected curves of imperfect solutions constructed according to Eq. (6).

In a situation where the deflection of a positive sign (expected wave formation in the plate) develops, the bifurcation diagram turns out to be more complex, since the straight line of the total deflection is inclined with respect to the load axis at an angle less than $90^{\circ}$ As a result, the curves of unconnected solutions with initial imperfections have two bifurcation points on each branch between which there is one limiting point. From equation (15) with the corresponding signs of the coefficients $d_{\mathrm{i}}$, we obtain (18):

$$
\mu_{1}^{2}-1.848 \mu_{1}+0.81351=0
$$




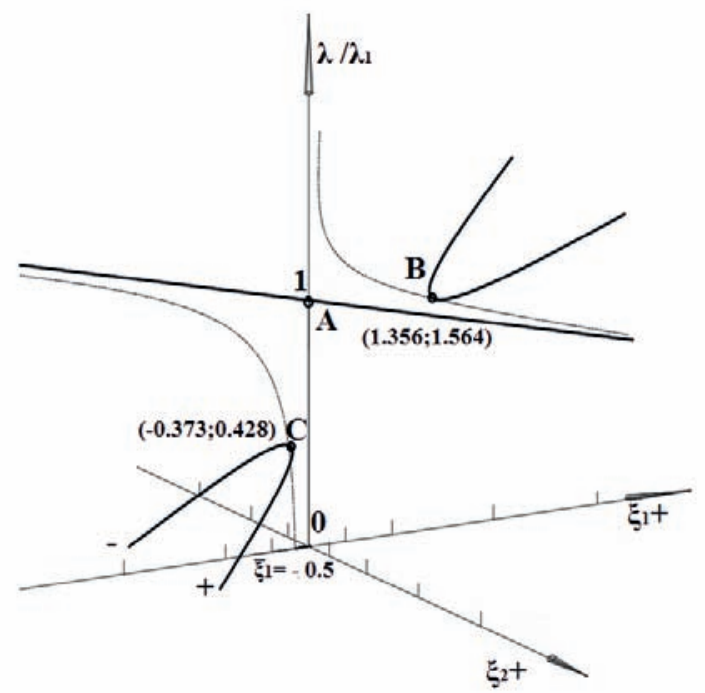

Figure 8. Bifurcation diagrams of related solutions (wave making of the stiffeners, $\overline{\xi_{1}}=-0.5$ )

Values of bifurcation loads:

$\mu_{1(1)}=1.125$ и $\mu_{1(2)}=0.723$
The coordinates of the bifurcation points are calculated by the formula (19):

$$
\xi_{1}=-\frac{\left(1-\mu_{1}\right)}{2 d_{1}} \mp \sqrt{\frac{\left(1-\mu_{1}\right)^{2}}{4 d_{1}^{2}}+\frac{\mu_{1} \overline{\xi_{1}}}{d_{1}}}
$$

Equating the discriminant of equation (19) to The coordinates of the limit points when two zero, we determine the load at the limiting values of $\mu_{1}$ are substituted: points:

$$
\mu_{1}^{2}+\left(2+\overline{\xi_{1}} 4 d_{1}\right) \mu_{1}+1=0
$$

$$
\xi_{1(1,2)}=-\frac{\left(1-\mu_{1}\right)}{2 d_{1}}
$$

We get: $\mu_{1(1)}=1.125$ и $\mu_{1(2)}=0.889$

The corresponding bifurcation diagram is shown in Figure 9.

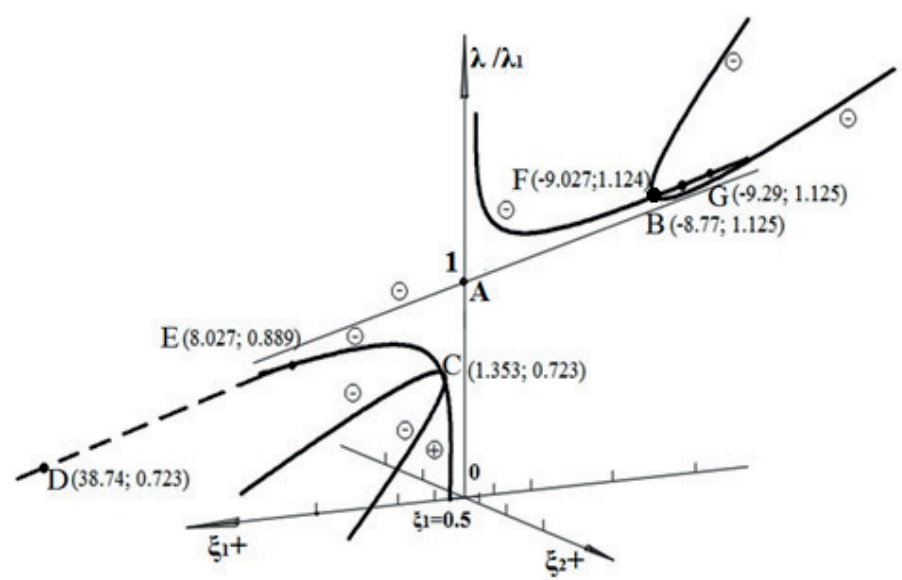

Figure 9. Bifurcation diagrams of related solutions (wave making of the plate, $\overline{\xi_{1}}=0.5$ ) 
Point B, C, D and $\mathrm{G}$ - points of wave formation bifurcation in the plate. Points $\mathrm{F}$ and $\mathrm{E}$ are limit points. Note that J. Hunt [2] previously predicted the constructed bifurcation diagrams using the example of concrete reinforced plates in general form based on energy considerations. The case of the appearance of limit points on the equilibrium curves is possible if in equations (2) and (3) the right-hand sides are not equal to zero $\left(\overline{\xi_{1}} \neq 0, \overline{\xi_{2}} \neq 0\right)$. One of the options for determining the critical loads and the coordinates of the limit points is to solve the fourth-degree equation with respect to the coordinates of the limit point:

$$
\begin{gathered}
d_{1} d_{3} \xi_{1}^{4}+\left[2 \mathrm{~d}_{1} \mathrm{~d}_{3}\left(1-k \mu_{1}\right)+\mathrm{d}_{3}^{2}\left(1-\mu_{1}\right)\right] \xi_{1}^{3}+ \\
+\left[2 \mathrm{~d}_{3}\left(1-\mu_{1}\right)\left(1-\mathrm{k} \mu_{1}\right)+\mathrm{d}_{1}\left(1-k \mu_{1}\right)^{2}-\mathrm{d}_{3}^{2} \mu_{1} \overline{\xi_{1}}\right] \xi_{1}^{2}+ \\
+\left[\left(1-\mu_{1}\right)\left(1-\mathrm{k} \mu_{1}\right)^{2}-2 \mathrm{~d}_{3}\left(1-k \mu_{1}\right) \mu_{1} \overline{\xi_{1}}\right] \xi_{1}+\left(\mathrm{k} \mu_{1}\right)^{2} \mathrm{~d}_{2} \bar{\xi}_{2}^{2}-\left(1-\mathrm{k} \mu_{1}\right)^{2} \mu_{1} \overline{\xi_{1}}=0
\end{gathered}
$$

Some solution results are given in the article by the authors [6]. Typical bifurcation

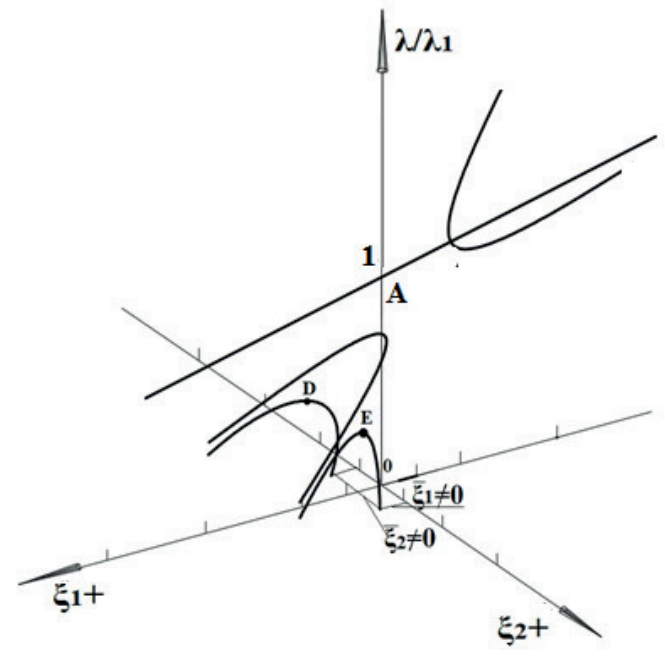

diagrams with limit points are shown in Figure 10.

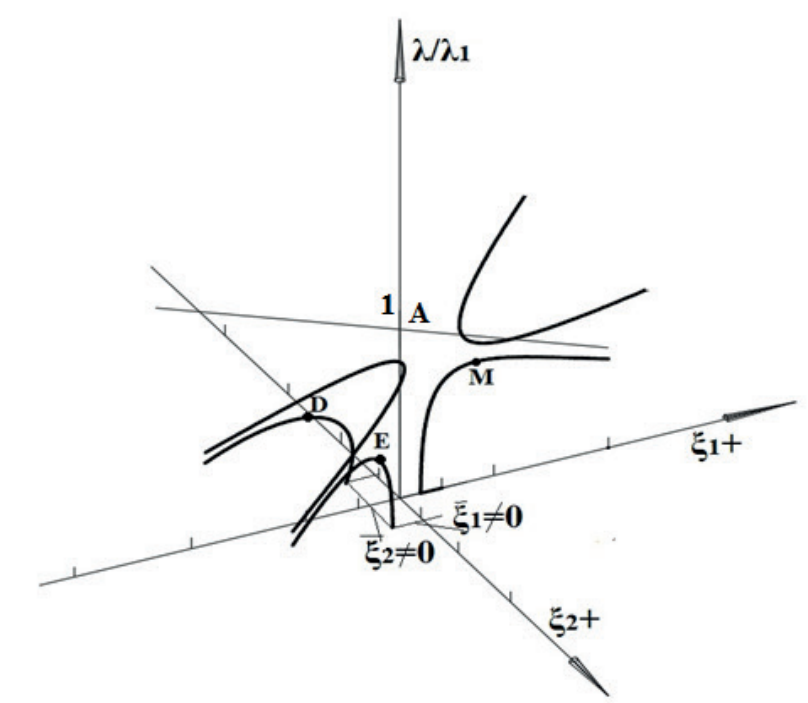

Figure 10. Bifurcation diagrams of related solutions with limit points, $\left(\overline{\xi_{1}} \neq 0, \overline{\xi_{2}} \neq 0\right)$

Note that the diagrams shown in Figures 6 and 7 correspond to the case when the critical loads of wave formation are less than the critical loads of the total deflection, since the post-bifurcation waveform is unstable, the bearing capacity of the reinforced plate is determined mainly by the sensitivity to initial imperfections by the type of waveforming.

If the geometry of the stiffened plate is changed so that the critical undulation load is greater than the critical load of the total deflection (Figure 11), then, in principle, it is possible to increase the bearing capacity of the reinforced plate by lifting it to a value close to the total deflection load. Bifurcation diagrams for cases where the critical load of wave formation exceeds the critical load of the total deflection ( $\mathrm{a}$ - the case of wave formation in the ribs, $b$ - the case of wave formation in the plate) are shown in Figure 11. 

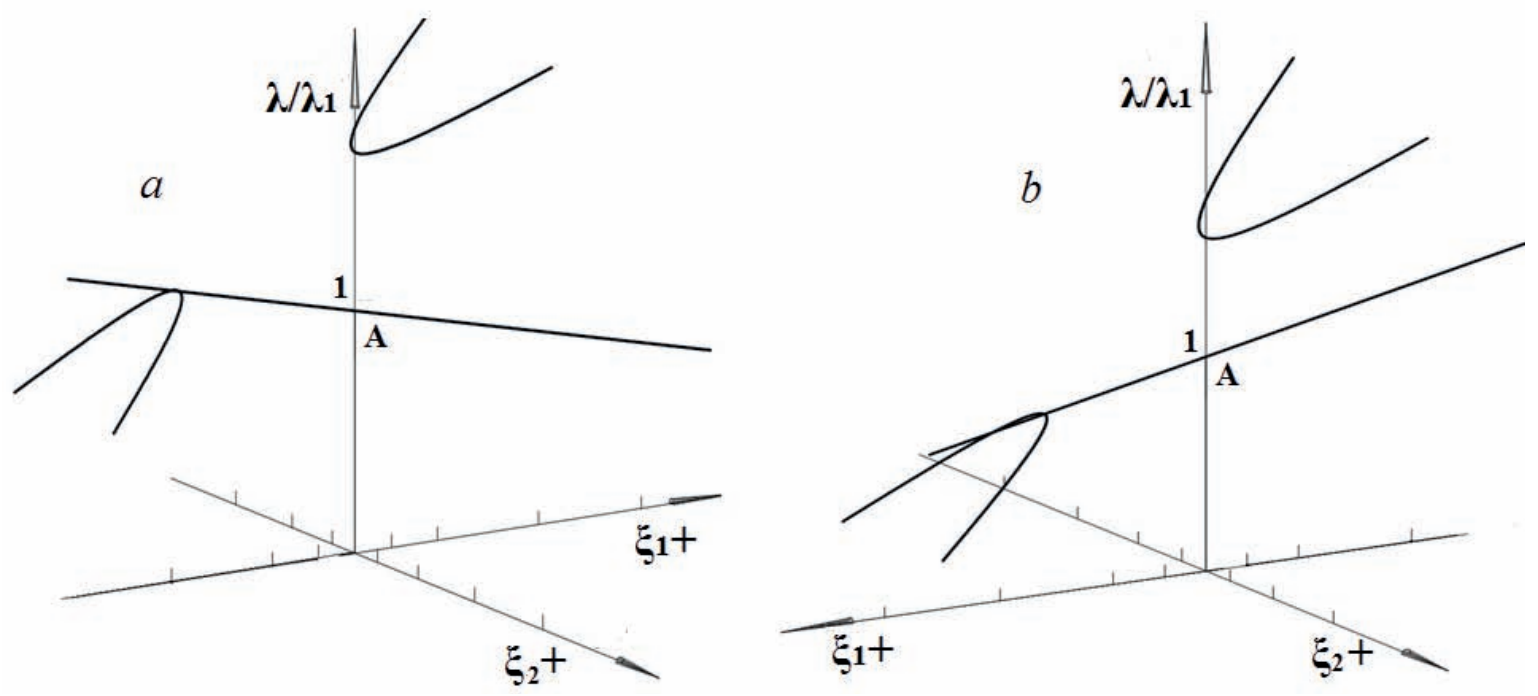

Figure 11. Bifurcation diagrams for the case of rational design of a stiffened plate

\section{REFERENCES}

1. Hunt G.W. (1977) // Imperfections and near-coincidence for semi-symmetric bifurcations (New York in Conference on Bifurcation Theory and Applications in Scientific Disciplines Ann. N. Y. Academy of Science 316) pp 572-589

2. Hunt G.W. (1981) // An algorithm for the nonlinear analysis of compound bifurcation (London Phil. Trans. R. Soc. Lond. A 1981 300) doi: 10.1098/rsta.1981.0075

3. Hunt G.W. (1977) // Imperfectionsensitivity of semi-symmetric branching (Proc. R. Soc. Lond. A 1977 357, 193-211) doi: 10.1098/rspa.1977.0163

4. Thompson J.M.T, Tan J.K.Y., Lim K.C. (1978) On the Topological Classification of Postbuckling Phenomena (Journal of Structural Mechanics Volume 6:4) pp. 383-414

5. Tvergaard V. (1973) // Imperfection sensitivity of a wide integrally stiffened panel under compression (Int. J. Solids Sructures 9) pp 177-192

6. Manuylov G., Kositsyn S., Grudtsyna I. (2021) // Geometrically nonlinear analysis of the stability of the stiffened plate taking into account the interaction of eigenforms of buckling Structural Mechanics And Analysis Of Constructions №17(1). c. 3-19

7. Manuylov G., Kositsyn S., Grudtsyna I. (2020) Influence of buckling forms interaction on stiffened plate bearing capacity International Journal for Computational Civil and Structural Engineering, 16(2), c. 83-93.

8. Manuylov G., Kositsyn S., Begichev M. (2016) // On stability loss of circular axially compressed cylindrical shell. part $1 / /$ International Journal for Computational Civil and Structural Engineering, 12(3), 5872

9. Manevich A.I. (1982) // On the theory of coupled loss of stability in stiffened thinwalled structures. Applicable mathematics and mechanics №2. p 337-345

10. Manevich A.I. (1981) // Interaction of forms of buckling failure of compressed stiffened panel. Structural Mechanics And Analysis Of Constructions №5. p 24-29

11. Manevich A.I. (1988) // Nonlinear theory of stability of stiffened plates and shells, with taking into account of buckling forms interaction. Dissertation abstract for procuring of the academic degree of Doctor of Engineering. p 8-25 


\section{СПИСОК ЛИТЕРАТУРЫ}

1. Hunt G.W. (1977) // Imperfections and near-coincidence for semi-symmetric bifurcations (New York in Conference on Bifurcation Theory and Applications in Scientific Disciplines Ann. N. Y. Academy of Science 316) pp. 572-589.

2. Hunt G.W. (1981) // An algorithm for the nonlinear analysis of compound bifurcation (London Phil. Trans. R. Soc. Lond. A 1981 300) doi: 10.1098/rsta.1981.0075

3. Hunt G.W. (1977) // Imperfectionsensitivity of semi-symmetric branching (Proc. R. Soc. Lond. A 1977 357, 193-211) doi: 10.1098/rspa.1977.0163

4. Thompson J.M.T., Tan J.K.Y., Lim K.C. (1978) On the Topological Classification of Postbuckling Phenomena (Journal of Structural Mechanics Volume 6:4) pp. 383414.

5. Tvergaard V. (1973) // Imperfection sensitivity of a wide integrally stiffened panel under compression (Int. J. Solids Sructures 9) pp 177-192

6. Мануйлов Г.А., Косицын С.Б., Грудцына И.Е. (2021) // Геометрическинелинейный расчет на устойчивость подкрепленной пластины с учетом взаимодействия собственных форм выпучивания // Строительная механика и расчет сооружений №17(1). с.3-19
7. Мануйлов Г.А., Косицын С.Б., Грудцына И.Е. (2020) // Влияние взаимодействия форм выпучивания на несущую способность подкрепленной пластины // International Journal for Computational Civil and Structural Engineering, 16(2), c. 83-93.

8. Мануйлов Г.А., Косицын С.Б., Бегичев М. (2016) // О явлении потери устойчивости продольно сжатой круговой цилиндрической оболочки. часть 1: о послекритическом равновесии оболочки // International Journal for Computational Civil and Structural Engineering, 12(3), 58-72

9. Маневич А.И. (1982) // К теории связанной потери устойчивости подкрепленных тонкостенных конструкций. Прикладная математика и механика №2. p. 337-345.

10. Маневич А.И. (1981) // Взаимодействие форм потери устойчивости сжатой подкрепленной панели. Строительная механика и расчет сооружений №5. с 2429.

11. Маневич А.И. (1988) // Нелинейная теория устойчивости подкрепленных пластин и оболочек с учетом взаимодействия форм выпучивания Автореферат на соискание ученой степени доктора технических наук. с 8-25
Gaik A. Manuylov, Ph.D., Associate Professor, Department of Structural Mechanics, Moscow State University of Railway Engineering (MIIT); 127994, Russia, Moscow, $9 b 9$ Obrazcova Street; phone/fax +7(499)972-49-81.

Sergey B. Kosytsyn, Advisor of RAASN, Dr. Sc., Professor, Head of Department of Theoretical Mechanics, Russian University of Transport (MIIT); 127994, Russia, Moscow, 9b9 Obrazcova Street; phone/fax: +7(499) 978-16-73; E-mail: kositsyn-s@yandex.ru, kositsyn-s@mail.ru

Irina E. Grudtsyna, PhD student of Department of Theoretical Mechanics, Russian University of Transport (MIIT); 127994, Russia, Moscow, 9b9 Obrazcova Street; phone/fax: +7(915) 351-95-09; E-mail: Grudtsyna_ira90@ mail.ru
Мануйлов Гайк Александрович, кандидат технических наук, доцент, доцент кафедры «Строительная механика» Российского Университета Транспорта (РУТ (МИИТ)); 127994, г. Москва, ул. Образцова, 9; тел./факс +7(499) 972-49-81

Косииьын Сергей Борисович, доктор технических наук, профессор, заведующий кафедрой «Теоретическая механика» Российского Университета Транспорта (РУТ (МИИТ)); 127994, г. Москва, ул. Образцова, 9; тел./факс +7(499) 97816-73; E-mail: kositsyn-s@yandex.ru, kositsyn-s@mail.ru

Грудиьнна Ирина Евгеньевна, ассистент кафедры «Теоретическая механика» Российского Университета Транспорта (РУТ (МИИТ)); 127994, г. Москва, ул. Образцова, 15; тел./факс +7(915) 351-95-09; E-mail: Grudtsyna_ira90@mail.ru 